\title{
Fertilitas Spermatozoa Ayam Buras dengan Penambahan Antioksidan Glutathione dalam Pengencer Ringer's Selama Simpan Dingin
}

\author{
Iswati $^{1}$, Nurul Isnaini ${ }^{2}$, Trinil Susilawati ${ }^{2}$ \\ 1) STPP Malang dan Mahasiswa Pascasarjana Fakultas Peternakan Universitas \\ Brawijaya Malang \\ 2) Bagian Produksi Fakultas Peternakan Universitas Brawijaya Malang
}

Corresponden author : ibuke.lintang@gmail.com dan trinil_susilawati@yahoo.com

\begin{abstract}
Testing of spermatozoa fertility in vivo is needed to find out the extent of the ability of spermatozoa fertilization in the female reproductive tract. The fertility ability of spermatozoa in fertilizing the ovum is indicated by the number of fertile eggs from the number of eggs incubated resulting from the mating with Artificial Insemination (AI). The aim of this research is to know the percentage of fertility of eggs from AI using semen which has been stored cold for 8 hours on Ringe's diluent with the addition of antioxidant glutathione. Collection semen with teaser female method is done in Poultry Breeder Installation of Sekolah Tinggi Penyuluhan Pertanian (STPP) Malang. The 30 female chickens were divided into 3 groups of treatment P0: AI using fresh semen with Ringer's diluent, P1: AI using cold semen with Ringer's Diluent ( 8 hours duration storage) and P2: AI using cold semen with $0.5 \mathrm{mM}$ addition in Diluent Ringe's (8 hours duration storage). Experiment design using Complete Randomized Design (CRD) and nonparametric data analysis with chi-square. The observed variable was egg fertility calculated based on egg fertility percentage. The results showed that the dilution treatment had a significant effect $(\mathrm{P}<0,05)$ on fertility egg, with the best result indicated by $\mathrm{P} 0$ that is $76 \%$ fertility, followed by P2 with fertility $42 \%$ and P1 which showed the lowest fertility was $34 \%$. AI with cold semen has not demonstrated a good percentage of fertility despite $0.05 \mathrm{mM}$ glutathione added as an antioxidant. It is recommended that AI in domestic poultry using fresh semen with Ringe's diluent, is done as soon as possible to obtain optimum fertility.
\end{abstract}

Keywords: fertility, domestic chicken, Artificial Insemination, glutathione, teaser female

\section{PENDAHULUAN}

Keberhasilan IB pada ayam tergantung pada beberapa faktor, antara lain: strain ayam, umur ayam, bahan pengencer dalam penyimpanan semen, derajat pengenceran atau dosis inseminasi, kualitas semen, deposisi semen, dan waktu inseminasi (Ridwan, 2008; Danang dkk., 2012,). Wiyanti dkk (2013), juga menyatakan bahwa faktor keberhasilan IB dipengaruhi oleh penampungan, penyimpanan, pengenceran semen, kesuburan betina, dan keterampilan inseminator. Hal ini diperjelas oleh Alkan, et al., (2002) bahwa keberhasilan IB sangat ditentukan oleh kualitas semen yang dikoleksi.Hal senada dilaporkan oleh Modupe et al.,(2013) bahwa kualitas semen berpengaruh penting terhadap fertilitas spermatozoa, konsentrasi spermatozoa $50 \times 10^{6}$ dilaporkan cukup untuk mencapai fertilitas yang baik pada ayam dan kalkun. Donoghue and Wishart (2000) menjelaskan pula bahwa beberapa faktor yang mempengaruhi 
fertilitas dalam program IB adalah kualitas semen yang dipengaruhi oleh hal-hal sebagai berikut : pejantan, pencahayaan, musim, berat badan, diet pakan dan koleksi semen.

Pada unggas, uji kualitas sperma mempunyai hubungan yang signifikan terhadap kemampuan fertilisasi. Prinsip umum uji kualitas sperma menggambarkan beberapa fungsi sperma yang ditunjukkan selama interaksinya di dalam saluran reproduksi betina dan ovum. Pada experimen yang lain uji fertilitas dikatakan memiliki hubungan yang rendah dengan uji kualitas spermatozoa. Hal yang menyebabkan rendahnya hubungan antara uji kualitas sperma dan kemampuan fertilisasi karena interaksi tersebut melibatkan banyak faktor sedangkan pengujian hanya memeperhatikan sedikit variabel (Wishart, 2009).Meskipun demikian fertilitas adalah suatu hal yang pertama dan paling penting dalam usaha pengembangan breeding pada unggas. Jumlah telur yang fertil yang dihasilkan pada penetasan menentukan profitabilitas dari seekor ayam. Meskipun pejantan dan betina keduanya memberikan pengaruh pada penurunan fertilitas, namun angka fertilitas yang rendah dianggap sebagai masalah besar pada pejantan (Khan, 2011).

Habibullah (2015) menjelaskan bahwa IB pada unggas adalah proses koleksi semen dari unggas jantan kemudian memasukkan semen ke dalam saluran reproduksi betina untuk mendapatkan telur yang fertil. Proses IB pada unggas seperti yang dikemukakan oleh Getachew (2016), semen dari unggas jantan dikoleksi kemudian dimasukkan ke oviduct unggas betina untuk mendapatkan fertilitas telur. Dosis semen yang dideposisikan di oviduct hendaknya memperhatikan kesehatan dan kesejahteraan unggas sehingga mencapai tingkat kesuburan yang tinggi. Volume semen yang dibutuhkan umumnya $0,1 \mathrm{ml}$, dengan konsentrasi minimal 100 - 200 juta spermatozoa per inseminasi, yang dimasukkan ke dalam vagina unggas betina. Hal senada diperjelas oleh Hopkins dan Evans (2003) dosis semen yang direkomendasikan untuk ayam adalah 0,1 ml dengan konsetrasi 300 juta spermatozoa. Syringe inseminasi dimasukkan ke dalam vagina ayam dengan kedalaman sekitar $3 \mathrm{~cm}$ dan semen dideposisikan pada posisi tersebut. Waktu yang direkomendasikan untuk IB adalah sore hari untuk menghindari adanya telur dalam uterus.

Kualitas spermatozoa secara in vitro dapat digunakan sebagai dasar dalam memperkirakan kemampuan fertilisasi spermatozoa, namun keberhasilan dalam membuahi ovum penting untuk diuji secara in vivo. Ukuran keberhasilan IB pada ayam adalah persentase fertilitas telur. Fertilitas ini menandakan terjadinya pembuahan antara spermatozoa dan ovum dalam saluran reproduksi betina ayam. Fertilitas telur merupakan jumlah telur yang fertil dari sejumlah telur yang diinkubasi hasil inseminasi buatan (Saleh dan Isyanto, 2011).

Inseminasi Buatan dengan menggunakan semen segar telah banyak dilakukan, penelitian Irastuti (2011) menyebutkan bahwa fertilitas telur ayam buras dengan interval IB 3 hari sekali sebesar 70,83 (\%). Perkembangan metode penyimpanan semen ayam dalam bentuk simpan dingin maupun simpan beku menuntut adanya evaluasi kualitas spermatozoa melalui uji fertilitas. Penelitian Saleh dan Isyanto (2011) menyatakan bahwa persentase fertilitas telur menurun seiring lama simpan semen pada suhu $10^{\circ} \mathrm{C}$, pada lama simpan 3 jam persentase fertilitas telur sebesar $56,18 \%$. 
Penambahan bahan pengencer yang dapat meningkatkan kemampuan fertilisasi telah dilakukan oleh Thananurak et al., (2015) yaitu dengan penambahan antioksidan glutathione yang mampu menghambat kerusakan membran akibat peroksidasi lipid selama pembekuan semen ayam,namun angka fertilitas masih rendah yaitu $62,08 \%$ pada penambahan $0,5 \mathrm{mM}$ glutathionepada media thawing semen beku ayam selama 1 jam pada suhu $5^{\circ} \mathrm{C}$. Penyimpanan yang lebih lama pada suhu $3-5^{\circ} \mathrm{C}$ dengan penambahan antioksidan glutathione dalampengencer semen ayam diharapkan mampu mempertahankan kualitas seprmatozoa sehingga mampu meningkatkan kemampuan fertilisasi, namun sejauh ini masih sebatas evaluasi invitro. Pengujian kualitas sepermatozoa secara invitro pada penelitian Danang dkk., (2012) memperlihatkan bahwa pada pengencer Ringer's spermatozoa ayam dapat bertahan selama penyimpanan dingin selama 18 jam, namun belum dilakukan uji fertilitas spermatozaoa secara in vivo. Penelitiansebelumya tentang penambahan glutathione pada pengencer Ringer's selama simpan dingin menghasilkan kualitas spermatozoa mampu bertahan pada konsentrasi $0,5 \mathrm{mM}$ selama 8 jam dengan motilitas individu, viabilitas dan abnormalitas berturut-turut sebesar $62 \pm 9,19 \%, \quad 79,26 \pm 8,49 \%$ dan $13,66 \pm 0,31 \%$.Berdasarkan hal tersebut perlu dilakukan pegujian fertilitas spermatozoa ayam buras dengan pengencer Ringer's yang ditambahkan $0,5 \mathrm{mM}$ glutathione setelah penyimpanan suhu $3-5^{\circ} \mathrm{C}$ selama 8 jam untuk mengetahui persentase fertilitas telur ayam buras.

\section{MATERI DAN METODE Materi penelitian}

Penelitian ini mengguankan ayam jantan sebanyak 2 ekor dengan umur 1 tahun dan 13 bulan, memiliki bobot badan 2,5 kg. Ayam buras betina sebanyak 30 ekor, dengan umur 40 minggu dan berat badan 1,7-2,2 kg. Ayam akseptor IB dibagi ke dalam 3 kelompok perlakuan sehingga masingmasing perlakuan sejumlah 10 ekor dengan perlakuan sebagai berikut: semen segar dengan pengencer Ringers (P0), semen dingin dengan pengencer Ringer dengan lama simpan 8 jam pada sugu $3-5^{\circ} \mathrm{C}(\mathrm{P} 1)$, dan semen dingin dengan penambahan gutathione $0,5 \mathrm{mM}$ dalam pengencer Ringer's yang telah disimpan pada suhu $3-5^{\circ} \mathrm{C}$ selama 8 jam (P2).

Peralatan yang digunakan untuk penampungan semen metode betina pemancingantara lain: spuit $1 \mathrm{ml}$, tabung plastik untuk menampung semen kapasitas $10 \mathrm{cc}$, tabung plastik dengan tali karet sebagai artificial cloaca, aluminium foil, spidol permanen, kertas label. Alat untuk pembuatan pengencer antara lain: erlenmeyer, magnetic strirer, kertas saring, timbangan analitik, tabung ukur, aluminium foil. Bahan pengencer yang digunakan antara lain: bahan pengencer berupa larutan Ringer's laktat yang mempunyai komposisi per $1000 \mathrm{ml}$ yaitu: Sodium klorida 6,0 g, Sodium Laktat 3,1 g, Potassium Klorida 0,3 g dan Kalsium Klorida $2 \mathrm{H}_{2} \mathrm{O} \quad 0,2 \mathrm{~g}$ (Danang dkk., 2012) dan bahan antioksidan Glutathione (Jincheng Pharm; CAS 7018-8).

Peralatan IB ayam antara lain : tabung tempat semen, spuit $1 \mathrm{cc}$ (spuit tuberculine) dengan bagian ujung dipasang selang karet steril dengan panjang $\pm 2-3 \mathrm{~cm}$. Perlatan penetasan adalah 1 unit mesin tetas otomatis dan 1 unit lampu peneropong (candling). 


\section{Metode penelitian}

Metode penelitian yang digunakan adalah eksperimental yaitu perlakuan IB menggunakan tiga pengencer terhadap masing-masing 10 ekor ayam buras betina.

\section{Penampungan Semen}

Penampungan semen dengan menggunakan metode betina pemacing (teaser female). Metode penampungan tersebut mengadopsi dari penelitian Chelmonska (2008) yang melakukan penampunagn semen pada burung puyuh tanpa pijat urut pada daerah abdomen hingga kloaka namun menggunakan rangsangan ayam betina.Penampung semen dilakukan dengan cara sebagai berikut : terlebih dahulu bulu disekitar kloaka dicukur, bagian sekitar bibir dan kloaka tersebut dibersihkan dari kotoran yang menempel dengan tissu yang dibasahi dengan alokol 70\%. Selanjutnya dipasang tabung sebagai artificial cloaca (Malecki and Martin, 2002)yang diikatkan pada punggung ayam, kemudian pejantan didekatkan pada betina pemancing dan pejantan akan muncul respon untuk menaiki betina, dalam beberapa detik ejakulasi akan terjadi dan semen tertampung dalam tabung artificial cloaca. Tali pengikat tabung dilepaskan dan semen yang tertampung di sedot dengan spuit $1 \mathrm{ml}$ untuk mengetahui valume semen, selanjutnya dituang dalam tabung yang berisi bahan pengencer.

\section{Inseminasi Buatan (IB)}

Ayam betina diinsemiansi dengan semen yang telah diencerkan sesuai dengan perlakuan. Inseminasi Buatan dilakukan 2 kali seminggu, dosis semen $0,2 \mathrm{ml}$ per ekor dengan konsentrasi spermatozoa 200 juta/ dosis IB. Ayam betina diinseminasi dengan metode intravaginal yaitu $2-4 \mathrm{~cm}$ dalam vagina. Inseminasi Buatan dilakukan pada sore hari jam 16.00 WIB, untuk menghindari adanya telur dalam uterus (Dononghue dan Wishart, 2000; Gethachew, 2016).

\section{Pengumpulan telur hasil inseminasi}

Koleksi telur dilakukan hari ke-2 sampai hari ke-6 setelah IB. Telur yang telah dikoleksikemudian dibersihkan darikotoran, telur diberi kode sesuai dengan tanggalbertelur, nomor ayam dan kelompok perlakuan.Telur yang telah ditandai dimasukan kedalammesin tetas yang telah difumigasi sebelumnya, dengan suhu $38^{\circ} \mathrm{C}\left(100^{\circ} \mathrm{F}\right)$. Pada hari ke tujuh inkubasi, telur diperiksa fertilitasnya dengan metode candling (peneropongan telur) untuk menentukan fertilitas telur (Tabatabaei, 2010).

\section{Parameter yang diamati}

Parameter yang diamati adalah persentase fertilitas telur. Telur yang dianggap fertil ditandai dengan adanya tunas dengan cabang-cabang urat darah dan telur infertil yang ditandai dengan titik atau lingkaran berwarna kehitaman. Persentase fertilitas menurut Modupe et al., (2013) dihitung dengan rumus sebagai berikut:

Fertilitas telur $(\%)=\frac{\text { Jumlah telur yang fertil }}{J \text { Jumlah telur yang ditetaskan }} \times 100 \%$

\section{Rancangan Ppercobaan dan analisis statistik}

Penelitian ini menggunakan

Rancangan Acak Lengkap (RAL) dengan 3 Perlakuan dan 10 ulangan. Perlakuan yang dicobakan adalah sebagai berikut :

$\mathrm{P} 0=$ semen segar dengan pengencer Ringer's

$\mathrm{P} 1=$ semen dingin dengan pengencer Ringer's (8 jam) 
$\mathrm{P} 2=$ semen dingin dengan pengencer Ringer's $+0,5 \mathrm{mM}$ glutathione ( 8 jam)

Data yang diperoleh di analisis dengan uji chi square untuk melihat apakah nilai pengamatan sesuai dengan nilai harapan dari fertilitas telur pada 3 perlakuan tersebut.

\section{HASIL DAN PEMBAHASAN}

Fertilitas telur dihitung dari total telur yang fertil di bagi dengan total telur yang diinkubasi dikalikan 100\% (Modupe et al., 2013). Hasil rataan fertilitas spermatozoa ayam buras dari ketiga perlakuan terterapada Tabel 1 .

Tabel 1. Rataan Fertilitas Spermatozoa Ayam Buras pada Tiap Perlakuan

\begin{tabular}{lr}
\hline Perlakuan & \multicolumn{1}{c}{ Rataan } \\
& Fertilitas $(\%)$ \\
\hline P0 & 76,0 \\
P1 & 34,0 \\
P2 & 42,0 \\
\hline
\end{tabular}

Berdasarkan Tabel 5, persentase fertilitas tertinggi ditunjukkan oleh semen segar dengan pengencer Ringer's (P0) yaitu $76 \%$. Persentase fertilitas dari semen dingin pada pengencer Ringer;s setelah penyimpanan 8 jam pada suhu $3-5^{\circ} \mathrm{C}$ menunjukkan penurunan fertilitas yaitu $34 \%$ (P1) dan penambahan glutathione dalam penyimpanan 8 jam pada suhu $3-5^{\circ} \mathrm{C}$ menunjukkan fertilitas sebesar $42 \%$ (P2). Hal ini sesuai hasil penelitian Solihati et al., (2006) bahwa fertilitas menurun pada IB dengan semen yang telah disimpan pada suhu 4$5^{\circ} \mathrm{C}$ pada lama simpan 1 jam $(43,24 \%)$, 24 jam $(21,68 \%)$ dan 48 jam $(10,32 \%)$. Hasil penelitian yang dilaporkan Saleh dan Isyanto (2011) menunjukkan bahwa pada penyimpanan $10^{\circ} \mathrm{C}$ menghasilkan fertilitas yang semakin menurun yaitu pada lama simpan 0 jam, 1 jam, 2 jam dan 3 jam dengan hasil fertilitas berturut-turut sebesar $80,80 \%, 60,50 \%$, $57,68 \%$, dan 56,18\%. Perbedaan hasil dari penelitian karena beberapa faktor antara lain strain ayam, umur, deposisi semen, konsentrasi semen, jumlah spermatozoa yang diinsemiansikan, jenis pengencer dan lama koleksi telur (Modupe et. al., 2013).

Inseminasi Buatan menggunakan semen segar dengan pengencer Ringer's pada penelitian ini menghasilkan fertilitas 76\%, lebih tinggi daripada penelitian Ridwan dan Rusdin (2008) yang melakukan IB menggunakan semen segar dengan pengencer Ringer's menghasilkan fertilitas $74,73 \%$. Hasil peenelitian ini juga menunjukkan fertilitas telur yang lebih tinggi dari penelitian Tabatabaei (2010) yang melakukan IB menggunakan semen segar dengan pengencer Ringer's pada dosis 100 juta per inseminasi yang menghasilkan persentase fertilitas optimum yaitu $72,37 \pm 5,28 \%$ sedangkan IB dengan dosis 200 juta per inseminasi menghasilkan fertilitas $89,12 \pm 3,74 \%$. Hal ini karena pengencer Ringer's mengandung Na-laktat diperlukan untuk mempertahankan keasaman larutan dan tekanann osmotik larutan (Danang, dkk., 2012). Pelaksanaan IB dilakukan paling lama 30 menit setelah koleksi semen sehingga belum terjadi metabolisme dan stress oksidatif yang berlebihan dibandingkan semen yang dilakukan penyimpanan dingin. Hal ini diperjelas oleh Getachew (2016) bahwa semen unggas akan kehilangan viabilitas setelah lebih dari 1 jam penampungan, sehingga inseminasi harus dilakukan sesegera mungkin setelah koleksi semen.

Hasil analisis antara pengenceran dengan persentase fertilitas dilakukan dengan uji non parametrik chi square. Berdasarkan nilai chi square 
yang lebih besar dari pada nilai tabel chi square, menunjukkan bahwa terdapat perbedaan yang nyata antara frekuensi yang teramati dengan frekuensi harapanpada perlakuan pengenceran terhadap persentase fertilitas telur. Persentase fertilitas yang diharapkan dari IB pada ayam adalah $89 \%$ (Tabatabaei, 2010). Pada penelitian ini,IB yang dilakukan menggunakan konsentrasi spermatozoa yang sama, tempat deposisi semen, inseminator dan waktu IB yang sama namun pengencer dan penyimpanan semen yang berbeda meghasilkan angka fertilitas yang berbeda. Hal ini sesuai pendapat Donoghue and Wishart (2000) bahwa variasi hasil analisis fertilitas disebabkan oleh pengencer yang berbeda, waktu insemiansi, kedalaman deposisi semen pada vagina, dosis spermatozoa dan frekuensi IB. Penyimpanan semen bisa berkisar anatar 6-48 jam, namun fertilitas nya menurun setelah penyimpanan 6 jam, bahkan penyimpanan lebih dari 24 jam akan semakin menurunkan angka fertilitas, karena diperkirakan lebih dari $30 \%$ spermatozoa yang hidup setelah penyimpanan 24 jam tidak mampu bertahan mencapai oviduct (Donoghue andWishart , 2000).

Persentase Fertilitas telur pada IB dengan semen yang telah disimpan selama 8 jam padasuhu $3-5^{\circ} \mathrm{C}$ pada pengencer Ringe's hanya sebesar 34\% hal ini diperkirakan karena selama simpan dingin spermatozoa mengaami stress oksidatif dan cold shock. Semen ayam mengandung berbagai macam asam lemak tak jenuh yang teroksidasi selama penyimpanan menghasilkan Reactive Oxygen Species (ROS). Oksigen spesies sangat aktive dalam level seluler menghasilkan berbagai derajat kerusakan sel spermatozoa. Sel spermatozoa rentan terhadap lipid peroksidase oleh radikal bebas seperti
Hidrogen peroksida, Superoksid anion, dan hydroxyl radical yang pada akhirnya menyebabkan kerusakan struktur membran seprmatozoa selama penyimpanan aerobic (Donoghue and Wishart, 2000; Zeitoun and Aldamegh., 2015). Cold shock selama penyimpanan semen memicu terjadinya stress pada membran sel spermatozoa melalui radikal bebas sehingga menyebabkan kerusakan spermatozoa (Sanocka and Kupisz, 2004; Thuwanut el al., 2011). Kerusakan pada membran spermatozoa berdampak pada rendahnya kemampuan fertilisasi dari spermatozoa yang secara invivo ditunjukkan dengan rendahnya angka fertilitas telur.

Upaya dalam melindungi spermatozoa selama penyimpanan dari kerusakan fisik maupun kimia antaralain adalah penambahan antioksidan enzymatic secara exogen atau penambahan dalam pengencer semen. Salah satu antioksidan itu adalah glutathione. Antioksidan memiliki mekanisme pertahanan dalam melawan lipid peroksidase dari semen dan memelihara motilitas dan viabilitas spermatozoa (Maia et al., 2009). Penambahan antioksidan glutathione dalam pengencer semen diharapkan menurunkan tingkat kerusakan membran spermatozoa sehingga kemampuan fertilisasi spermatozoa dapat dipertahankan.

Hasil penelitian ini menunjukkan bahwa persentase ferrtilitas telur dari pengencer semen ayam yang telah ditambah dengan antioksidan glutathione $0,5 \mathrm{Mm}$ sebesar $42 \%$, hasil ini belum mampu menunjukkan fertilitas yang tinggi seperti IB dengan semen segar tanpa penyimpanan. Penambahan antioksidan glutathione diharapkan dapat menangkal reaksi peroksidase lipid sehingga mampu bertahan selama penyimpanann dingin. Berdasarkan 
hasil evaluasi spermatozoa selama penyimpanan dingin 8 jam, secara visual masih menunjukkan kualitas spermatozoa yang layak untuk IB yang dilihat dari parameter motilitas individu $62 \%$, viabilitas $79,26 \%$ dan abnormalitas spermatiozoa $13,66 \%$. Akan tetapi uji in vivomelalui aplikasi IB belum mampu menunjukkan fertilitas yang lebih baik dibandingkan IB dengan semen segar.Hal senada dilaporkan pula oleh Thananurak (2015) bahwa penambahan glutathione $0,5 \mathrm{mM}$ pada post thawing semen beku ayam selama 1 jam, persentase fertilitasnya mencapai $62,08 \pm 1,23 \%$ dan lebih rendah dibandingkan IB tanpa penambahan glutathione dalam pengencer semen. Menurut Donoghue and Wishart (2000), kemampuan fertilisasi dari semen beku unggas setelah di thawing dipengaruhi oleh dosis spermatozoa, frekuensi inseminasi dan deposisi semen dalam saluran reproduksi betina. Deposisi semen dilakukan pada bagian intravaginal, spermatozoa akan menuju daerah uterovagina sebagai Sperm Storage Tubules (SSTs) yang selanjutnya akan melakukan pergerakan menuju infundibulum untuk melakukan fertilisasi. Akan tetapi hanya spermatozoa yang potensial dan terseleksi yang dapat mencapai tempat fertilisasi (Ridwan dan Rusdin, 2008). Spermatozoa dapat kehilangan fertilitas walaupun secara visual masih hidup karena untuk mencapai tempat fertilisasi dipengaruhi oleh beberapa faktor antara lain adalah transport melewati vagina masuk ke dalam Sperm Storage Tubules (SSTs) yang memerlukan motilititas spermatozoa. Akan tetapi Motilitas yang tepat tidak cukup untuk memastikan pembuahan, karena sperma harus melewati proses fisiologis kapasitasi dalam saluran reproduksi betina. Transport dari SSTs menuju infundibulum juga memerlukan kontraksi uterus. Setelah sampai pada tempat fertilisasi membutuhkan pengikatan antara bagian inner periviteline (Wishart., 2009).

\section{KESIMPULAN}

Pengenceran dan penyimpanan semen ayam pada suhu $3-5^{\circ} \mathrm{C}$ menunjukkan pengaruh yang nyata terhadap fertilitas spermatozoa ayam buras. Inseminasi Buatan dengan menggunakan semen segar menunjukkan hasil yang terbaik pada persentase fertilitas telur, sedangkan IB dengan semen yang telah disimpan selama 8 jam pada suhu $3-5^{\circ} \mathrm{C}$ belum memberikan hasil yang lebih baik meskipun telah ditambahkan antioksidan glutathione dalam pengencer dasar Ringer's. Penggunaan semen segar ayam yang telah diberi pengencer Ringe's untuk aplikasi IB sebaiknya dilakukan sesegera mungkin untuk memperoleh fertilitas yang iptimum.

\section{DAFTAR PUSTAKA}

Alkan, S., A. Baran, O.B. Ozdas dan, M. Evecen 2002. Morfological defects in turkey semen.Turk.J.Vet. Animal Science. 26:10871092.

Chelmonska, B., A. Jerysz, E. L Ukaszewicz, A. Kowalczyk, I. Malecki. 2008. Semen Collection from Japanese Quail (Coturnix japonica) Using a Teaser Female.Turk.J. Vet. Anim. Sci.32(1): 19-24

Danang, D.R, N. Isnaini dan P.Trisunuwati. 2012. Pengaruh Lama Simpan Semen Terhadap Kualitas Spermatozoa Ayam Kampung Dalam Pengencer Ringer's pada suhu 
$4^{\circ}$ C.Jurnal Ternak Tropika . 13 (1): 47-57

Donoghue. A.M., and G.J.Wishart (2000). Storage of poultry semen. Animal

Reproductive Science, 62: 213-232.

Getachew, T. 2016. A Review Article of Artificial Insemination in Poultry. World's Veterinary Journal. 6 (1):26-35.

Habibullah, M., M. A. Hashem, M. S. Rana and $M$. H. Islam. 2015. Effect of Artificial Insemination on different production parameter in Hubbard classic broiler parent stock. J. Bangladesh Agril. Univ. 13(1): 71-77.

Hopkins, S.M. and L.E.Evans. 2003. Artificial Inseminations in McDonald's Veterinary Endocrinology and Reproduction.Edited by Mauricho H. Pineda and Michael P.Dooley. $5^{\text {th }}$ edition. Iowa statePress. USA: 366-368.

Irastuti. 2011. Pengaruh Bangsa Pejantan dan Interval Deposisi Sementerhadap Keberhasilan Inseminasi Buatan pada ayam. Jurnal Sains dan Teknologi Tadulako. 1(1): 13-25.

Khan, R.U. 2011. Antioxidant and Poultry Semen Quality.World's Poultry Science Journal.67: 298308.

Maia, M.S., S.D. Bicudo, H.C. Azevedo, C.C. Sicherle, D.B. Sousa, and L. Rodello. 2009. Motility and Viability of Ram Sperm Cryopreserved in a Tris-Egg Yolk Extender Supplemented with Anti-
Oxidants. Small Ruminant Research. 85: 85-90.

Malecki, I., and G.B Martin. 2002. Semen collection in the emu and ostrich.Proceedings of the World Ostrich Congress. Warsaw, Poland: 38-43.

Modupe, O., A. C Livinus and N.B. Ifeany. 2013. Semen Quality Characteristic and Effect of Mating Ratio on Reproductive Performance of Hubbarrd Broiller Bredders. Journal of Agriculture Science. 5(1) 154-159.

Ridwan dan Rusdin. 2008. Konservasi Semen Ayam Buras Menggunakan Berbagai Pengencer Terhadap Fertilitas Dan Periode Fertil Spermatozoa Pasca Inseminasi Buatan.J. Agroland 15 (1) : 63 - 67.

Saleh D.M., dan A.Y. Isyanto . 2011.

Pengaruh Lama

Penyimpanan terhadap Motilitas dan Fertilitas Spermatozoa Ayam Kate Lokal. Ckrawala Galuh. 1(6): 1-6.

Sanocka, D.M. and Kurpisz, M. 2004. Reactive Oxygen Species and Sperm Cells. Reproductive Biology and Endocrinology. 2: 12-18.

Solihati, N., A. Pinnezak R. Idi, R. Setiawan, I.Y. Asmara, B.I. Sujana., 2006. Pengaruh Lama PenyimpananSemen Cair Ayam Buras pada Suhu $5^{\circ} \mathrm{C}$ terhadap Periode Fertil dan Fertilitas Sperma.Jurnal Ilmu ternak. 6(1):7-11

Surai, P.F., N. Fujihara, B.K. Speake, JP.Brillard, G.J. Wishart and N.H.C.Sparks. 2001. 
Polyunsaturated Fatty Acids, Lipid Peroxidation and Antioxidant Protection in Avian semen. Review. Asian-Aust,J.Animal science. 14 (7): 1024-1050.

Tabatabaei, S. 2010. The effec Spermatozoa Number on Fertility Rate of Chicken in Artificial Insemination Programs. Journal of Animal and Veterinary Advances. 9(12): 17171719.

Thananurak, P.,C. Sittikasamkit, T. Vongpralub and K. Sakwiwatkul. 2015. Effects of Addition of Reduced Glutathione to Thawing media on Motility Parameters, Lipid Peroxidation and Fertility Rate in Frozen-Thawed Chicken Spermatozoa. Khon Kaen Agr Journal. 43 (suplement 2): 98-102.
Thuwanut, P., K. Chatdarong, A.S Bergqvist, L. Söderquist, K. Thiangtum, D Tongthainan, and E. Axnér. 2011. The Effects of Antioxidants on Semen Traits and in Vitro Fertilizing Ability of Sperm from Flat-Headed Cat (Prionailurus planiceps). Theriogenology. 76: 115125.

Zahariev Z., R. Stefanof., M. Sabev., K. Miteva., and I. Nikolav.,2007. Cytochrome Affect Viability and Fertility of Bull Semen, am-Euras. J. Agric and Environ.2(1): 4850 